\title{
LETTER TO NPT
}

August 21, 2013

Editor, New Perspectives on Turkey:

Your journal recently published a misleading review of my monograph, Honored by the Glory of Islam: Conversion and Conquest in Ottoman Europe (Oxford 2008) (NPT No. 48, Spring 2013). It is astonishing that the reviewer's main point of criticism is actually one of the major arguments that $I$ make in the book. The reviewer states that the chronicles which I use offer idealized images of the sultan, telling the modern historian how Mehmed IV wanted to be remembered for posterity, but cannot be read at face value. I could not agree more completely. In fact, this is a perfect summary of the approach I take toward these sources. As evidence, any objective reader of the book would find the following:

1. The historical material used for the study "provides the historian insight into how elite men and women at that time shaped, formed, and articulated their understanding of the moment in which they lived and the cultural value of conversion in that era" (p. 23).

2. Chapter five explores this point in depth, namely how historical events and history writing are entwined. I state that the chronicle of Abdi $\mathrm{Pa}$ sha, one of the major sources for the study, "is an invaluable work for presenting views of events from the sultan's perspective and how he wished to be remembered, and provides insight into which events were deemed important for posterity and which were passed over in silence" (p. 106).

3. I also explain how, because Abdi Pasha "was appointed to write a work that praises the sultan to posterity" then "one cannot uncritically use Abdi Pasha's chronicle as a biographical source" (ibid.)

4. As I continue,"a life and a legacy are not the same thing; the latter is usually considered a vision of reality shaped by those who thought and wrote about the subject, for their own reasons, after the life to be retold had ended. In this case, the legacy was shaped in the narrative of the sultan's life mediated by his official historian in part by the sultan while he was still living. His story is also about the construction and presentation of a sultan's historical persona by a select group of elite men, many of whom were partners in power, promoting their parron, who shaped the meaning of his life for fellow Ottomans" (p. 107). 
5. I explore this further in "Mehmed IV's Posthumous Reputation" (p. 240-44), where I discuss how writers approached the reign of Mehmed IV after his dethronement, which stands in great contrast to how he was depicted when in power.

A review that criticizes an author for failing to do what the author has actually done-repeatedly and explicitly-performs a disservice to readers of your journal. The reviewer has misrepresented Honored by the Glory of Islam, by presenting the author's critical approach as his own, and attempting to turn it against the author. Accordingly, facing such a misleading review, the reader is urged to check all other claims that the reviewer makes against what is actually stated in the monograph.

\section{Marc David Baer}

The London School of Economics 